\section{Direct transfer of genetic materi- al between two Escherichia coli K12 strains by electroporation}

\author{
Anna Marchese, ${ }^{1,2}$ Eugenio A. Debbia ${ }^{1}$ \\ ${ }^{1}$ C.A. Romanzi Section of Microbiology, \\ Department of Surgical Sciences and \\ Integrated Diagnostic (DISC), \\ University of Genoa, ${ }^{2}$ Microbiological \\ Unit, San Martino Polyclinic Hospital, \\ Genoa, Italy
}

\begin{abstract}
A direct transfer of plasmid pBP517 from C600 to J53 Escherichia coli K12 strains by electroporation, either by the standard method, or in the presence of 20 $\mu \mathrm{g} / \mathrm{mL}$ of DNAse was carried out. In a standard experiment, donor and recipient bacteria were mixed and subjected to the electroporation procedure, about 2700 (range 1600-3700) recombinants were found, while no colonies were detected from non treated bacteria. When the same tests were performed at the presence of DNAse the number of recombinants fell to about 200 (range 183-218). This difference between the number of colonies found in the presence or in absence of DNAse was observed every time the tests were repeated. According to these observations, plasmid DNA has been transferred from donor to recipient cells via electroporation also when DNAse was added. Since the free genetic material is destroyed by the enzyme and recombination takes place it has been hypothesized that there must be a direct contact between the partner cells.
\end{abstract}

\section{Methodology}

Electroporation is a system to introduce transient pores into membranes of mammalian cells by a high-intensity electric field. This technique is use to diffuse or exchange intracellular and extracellular material among the cells during the lifespan of the pore. These electric impulses have also demonstrated to promote eukaryotic cell fusion. ${ }^{1,2}$ Electroporation is also an increasing recognized method for introducing DNA into bacterial cells and for promoting plasmid loss from bacteria. , $^{3,4}$ In particular this technique was employed in transformation experiments to stimulate the uptake of plasmid DNA, and in direct transfer of genetic material to recipient cells not only among organisms of the same species, but also among bacteria genetically not cor- related to each other. ${ }^{2}$ Many different experimental conditions were also explored to enhance the efficiency of DNA and proteins exchange. ${ }^{5-8}$ Previous experiments from this laboratory showed that an apparatus, used for endodontic treatments, that generated a high frequency alternating current $\left(\right.$ Endox ${ }^{\circledR}$ Endodontic System (Endox) ${ }^{9}$ presented many analogies with the electric pulses generator employed for electroporation. Although the mode by which this apparatus causes the death of the bacteria is not known, it was used to carry out experiments to achieve a high permeability of the cell envelope of different microorganisms. This instrument demonstrated a lethal activity on different strains representative of gram-positive and gram-negative bacterial species as well as Candida albicans, Actinomyces spp, and Bacillus subtilis spores. ${ }^{10}$ This apparatus after changing the set of electrical parameters, was also used to perform genetic experiments promoting the exchange of non-conjugative plasmid DNA between two Escherichia coli K12 strains, mixed together and then exposed to this electric pulses. Further tests demonstrated that this instrument promoted the entry into the bacterial cell of antibiotics that are not normally able to interact with the microorganism because of a natural permeability barrier, and induced a delay in the re-growth of survivors of different species following this treatment. ${ }^{11}$ These findings prompted us to explore if it is possible to exchange genetic material mixing donor and recipient bacterial cells using the instrument generally employed in the electroporation experiments. In the same time it appeared of a certain interest verify if the addition of DNAse during electroporation inhibit any genetic material exchange. To explore this possibility, a direct transfer of plasmid pBP517, ${ }^{12}$ from $E$ coli K12 laboratory strains C600 (donor) and J53 (recipient) by electroporation, either by the standard method, or in the presence of $20 \mu \mathrm{g} / \mathrm{mL}$ of DNAse was carried out. In a standard test, donor and recipient strains were harvested from culture in logarithmic phase and washed three times with ice-cold water. The final bacteria concentration was about $3 \times 10^{10}$ cells in $1 \mathrm{~mL}$. $40 \mu \mathrm{L}$ aliquots of both donor and recipient strain were mixed and transferred to an icecold electroporation cuvette. The mixture was exposed to a single pulse of $2.4 \mathrm{kV}, 25$ $\mu \mathrm{F}$ (time constant $4.6 \mathrm{~m} / \mathrm{sec}$ ) in a Gene Pulser unit (Bio-Rad Laboratories, Milan, Italy). $1 \mathrm{~mL}$ of SOC solution ( $2 \%$ tryptone, $0.5 \%$ yeast extract, $10 \mathrm{mM} \mathrm{NaCl}, 2.5 \mathrm{mM}$ $\mathrm{KCl}, 10 \mathrm{mM} \mathrm{MgCl} 2,10 \mathrm{mM} \mathrm{MgSO} 4$, and $20 \mathrm{mM}$ glucose) was added and the treated cells were incubated at $37^{\circ} \mathrm{C}$ for two hours. Recombinants were selected on plates con-
Correspondence: Eugenio A. Debbia, C.A. Romanzi Section of Microbiology, Department of Surgical and Diagnostic Sciences, University of Genoa, Largo Rosanna Benzi 10, 16132 Genoa, Italy. Tel.: +39.010.353.38136 - Fax: +39.010.353.7651. E-mail: eugenio.debbia@unige.it

Key words: contact between bacterial cells, electroporation, direct DNA transfer.

Contributions: both authors contributed equally.

Conflict of interest: the authors declare no potential conflict of interest.

Funding: the study was supported by the C.A. Romanzi Section of Microbiology, Department of Surgical Sciences and Integrated Diagnostics, (DISC), School of Medical and Pharmaceutical Sciences, University of Genoa, Italy.

Received for publication: 13 July 2017.

Accepted for publication: 18 September 2017.

This work is licensed under a Creative Commons Attribution NonCommercial 4.0 License (CC BY-NC 4.0).

(C) Copyright A. Marchese and E.A. Debbia, 2017 Licensee PAGEPress, Italy

Microbiology Research 2017; 8:7311

doi:10.4081/mr.2017.7311

taining rifampin $(100 \mu \mathrm{g} / \mathrm{mL})$ and amikacin $(40 \mu \mathrm{g} / \mathrm{mL})$, that enable the growth of the recipient cells that acquired the pBP517 plasmid from the donor. Some random chosen colonies were also checked for the presence of the plasmid DNA by agarose gel electrophoresis (Figure 1). In a standard experiment about 2700 (range: 1600-3700) recombinants were found, while no colonies were detected from non treated bacteria. When the same tests were performed at the presence of DNAse the number of recombinants fell to about 200 (range: 183-218). This difference between the number of colonies found when DNAse was included in the mixture and when it was omitted was observed every time the tests were repeated.

According to these observations, plasmid DNA has been transferred from donor to recipient cells via electroporation also when DNAse was added during all the experimental procedure.

In an attempt to explain the present findings some hypotheses and considerations can be argued. When the bacterial cells are exposed to the electric field, the genetic materials and other cellular components are released from the donor strain and introduced into the recipient through the 
transient pores also present in the partner cells. The strong reduction of the number of recombinants when DNAse was added suggests that the free genetic material is digested by the enzyme, The low number of recombinants still obtained under these experimental conditions might be due to the presence of residual DNA not completely eliminated by the enzyme. On the other hand, the pores appear stable and can be seen under an electronic microscope, ${ }^{2-13}$ bacterial cells that are not totally killed by the treatment and required about 1 hour to resume their original growth rate, ${ }^{11}$ might have enough time to acquire the residual genetic material or establish a direct contact between each other. It is also possible that when pores are formed might fit together with those of the partner cells establishing a direct cell to cell connection enabling all cytoplasmic material to be exchange.

Preset findings demonstrate that genetic material can be exchange between two bacterial cells treated together to electropora-

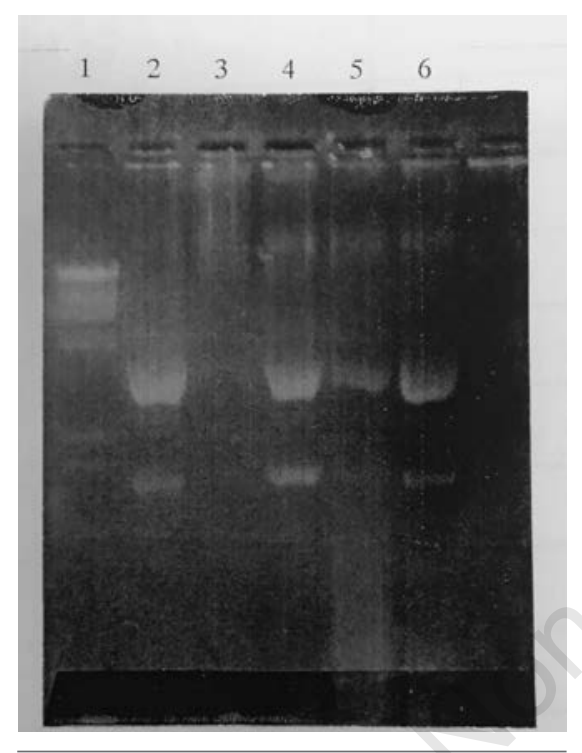

Figure 1. Plasmid DNA from donor (lane 2 ), recipient (lane 3 ) and recombinant cells (lanes 4, 5, and 6). Lane 1, $\lambda$ DNA Eco RI. tion. This is a interesting finding in view of the fact that routine method in both grampositive and gram-negative bacteria require tedious time and material consuming techniques via a spheroplast formation of the bacterial cells. ${ }^{14}$

Electroporation is rapid and prompts to explore new fields in genetic recombination interspecies as well as intra-species by passing the difficulties due to the complexity of bacterial cell wall especially in gram-negative organisms. ${ }^{15-18}$

\section{References}

1. Tieleman DP. The molecular basis of electroporation. BMC Biochemistry 2004;5:10.

2. Kotnik T, Frey W, Sack M, et al. Electroporation-based applications in biotechnology. Trends Biotechnol 2015;33:480-8.

3. Calvin NM, Hanawalt PC. High-efficiency transformation of bacterial cells by electroporation. J Bacteriol 1988; 170:2796-801.

4. Heery DM, Powell R, Gannon F, et al. Curing of a plasmid from E. coli using high-voltage electroporation. Nuc Acids Res 1989;17:10131.

5. Hu J, Cutrera J, Li S. The impact of non-electrical factors on electrical gene transfer Methods Mol Biol 2014;1121: 47-54.

6. Tu Q, Yin J, Fu J, et al. Room electrocompetent bacterial cells improve DNA transformation and recombineering efficiency. Sci Rep 2016;6:24648.

7. Haberl-Meglič S, Levičnik E, Luengo $\mathrm{E}$, et al. The effect of temperature and bacterial growth phase on protein extraction by means of electroporation Bioelectrochemistry 2016;112:77-82.

8. Garcia PA, Ge Z, Kelley LE, et al. High efficiency hydrodynamic bacterial electrotransformation Lab Chip 2017;17:490-500.
9. Cassanelli C, Armanino R, Debbia EA et al. Valutazione dell'attivita' battericida dell'endox, un nuovo strumento per la terapia endodontica, su vari microrganismi. Dentista Moderno 2005;23:7180.

10. Cassanelli C, Roveta S, Cavallini F, et al. Bactericidal effect of Endox against various pathogens. Clin Microbiol Infect 2004;10:480.

11. Cassanelli C, Marchese A, Cagnacci S, et al. Alteration of membrane permeability of bacteria and yeast by high frequency alternating current (HFAC). Open Microbiol J 2008;2:43-8.

12. Heisig P. High-level fluoroquinolone resistance in a Salmonella typhimurium isolate due to alteration in both gyrA and gyrB genes. J Antimicrob Chemother 1993;32:367-77.

13. Meglic HS, Marolt T, Miklavcic D. Protein extraction by means of electroporation from E.coli with preserved viability. J Membrane Biol 2015;248:893901.

14. Reina S, Debbia EA, Schito GC. Genetic recombination by spheroplast fusion in Escherichia coli K12. Cytobios 1993;76:91-95.

15. Beare PA, Sandoz KM, Omsland A, et al. Advances in genetic manipulation of obligate intracellular bacterial pathogens. Front Microbiol 2011;2:113.

16. Brisson D, Drecktrah D, Eggers CH, et al. Genetics of Borrelia burgdorferi. Annu Rev Genet 2012;46.

17. Kolek J, Sedlar K, Provaznik I, et al. Dam and Dcm methylations prevent gene transfer into Clostridium pasteurianum NRRL B-598: development of methods for electrotransformation, conjugation, and sonoporation. Biotechnol Biofuels 2016;9:14.

18. Biswas I. Genetic tools for manipulating Acinetobacter baumannii genome: an overview. J Med Microbiol 2015;64;657-69. 